Syntax Fusion : Jurnal Nasional Indonesia

p-ISSN: -

e-ISSN : 2775-4440

Vol. 1, No. 7, Juli 2021

\title{
PENGARUH MEDIA PEMBELAJARAN BERBASIS AUDIO VISUAL TERHADAP MINAT BELAJAR SISWA DI PESANTREN AINUL HASAN
}

\author{
Hasan Mubarok, Moh. Umar Aliansyah, Sofiyatun Maimunah, dan Magfirotul \\ Hamdiah \\ Universitas Islam Zainul Hasan (UNZAH) \\ Email: umarganteng1235678910@gmail.com, hasanainzha@gmail.com, \\ sofiyatunmaimunah@gmail.com dan magfirotulhamdiah@gmail.com
}

\begin{abstract}
Abstrak
Penelitian ini akan mengkaji atau menganalisi tentang sebuah media pembelajaran berbasis audio visual untuk meningkatkan minat belajar siswa dalam pesantren, dan Penelitian ini menguak pembelajaran menggunakan audio visual didalam pesantren Ainul Hasan yang masih belum terjamah atau menerapkan media audio visual, tentunya membantu untuk lebih mengefesienkan pembelajarn yang ada didalam pondok pesantren Ainul Hasan. Teknik yang digunakan ialah teknik analisis data dan teknik pemgumpulan data agar pemorolehan data sangat efesien serta akurat. Dengan adanya audio ini kita dapat mengambil pandangan atau sebuah nilai dengan adanya media audio visual tentang seberapa berpengaruhkah media audio visual yang akan ada di dalam pondok pesantren salahsatunya PP. Ainul Hasan.
\end{abstract}

Kata Kunci: Media pembelajaran, audio visual dan pondok pesantren

\section{Pendahuluan}

Pondok pesantren merupakan rangkaian kata yang terdiri dari pondok dan pesantren. Kata pondok (kamar, gubuk, rumah kecil) yang dipakai dalam bahasa Indonesia dengan menekankan kesederhanaan bangunannya. Kata pondok berasal dari bahasa arab "funduk" yang berarti ruang tempat tidur, wisma atau hotel sederhana. Pada umumnya pondok memang merupakan tempat penampungan sederhana bagi para pelajar yang jauh dari tempat asalnya. Secara garis besar dan secara umum (awam), tipologi pesantren terbagi menjadi dua bagian, yaitu pesantren tradisional dan pesantren modern. Dalam pesantren tradisional, setiap system pengajaran maupun materi yang disampaikan masih serba klasik. Pengajaran islam secara mendalam diambil dari kitab-kitab kuning masih sangat 
Hasan Mubarok, Moh. Umar Aliansyah, Sofiyatun Maimunah, dan Magfirotul Hamdiah

mendominasi, sedangkan metode penyajiannya, sangat konvensional seperti sorogan, bandongan, ceramah (khotbah) maupun hafalan.

Pesantren moderen banyak sekali hal-hal baru yang ada dalam pesantren tersebut. Salah satunya adalah dengan adanya sebuah media pembelajaran yang lebih menarik, sehingga santri atau siswa yang belajar dalam pesantren tersebut lebih bersemangat lagi dalam belajar. Pengertian media mengarah pada sesuatu yang dapat meneruskan informasi (pesan) antara sumber (pemberi pesan) dan penerima pesan. Media merupakan segala bentuk dan saluran yang digunakan menyampaikan pesan atau informasi (AECT dalam Arsyad, 2011). Sejalan dengan hal tersebut Munadi (2012) menyatakan bahwa "media merupakan segala sesuatu yang dapat menyampaikan dan menyalurkan pesan dari sumber secara terencana sehingga tercipta lingkungan belajar yang kondusif di mana penerimanya dapat melakukan proses belajar secara efisien dan efektif'.

Media pembelajaran dapat dikatakan sebagai alat bantu pembelajaran, yaitu segala sesuatu yang dapat dipergunakan untuk merangsang pikiran, perasaan, perhatian dan kemampuan atau ketrampilan peserta didik sehingga dapat mendorong terjadinya proses belajar. Batasan ini masih cukup luas dan mendalam mencakup pengertian sumber, lingkungan, manusia dan metode yang digunakan untuk tujuan pembelajaran.

Media pembelajaran biasanya dipahami sebagai benda-benda yang dibawa masuk ke ruang kelas untuk membantu efektivitas proses belajar mengajar. Pemahaman sempit ini dipengaruhi oleh pandangan cognitivism yang melihat proses belajar sebagai transfer pengetahuan dari pengajar ke peserta didik yang kebanyakan berlangsung dalam ruang kelas. Jika menggunakan pandangan constructivism maka pengertian belajar dan media pembelajaran menjadi lebih luas. Media pembelajaran tidak terbatas pada apa yang digunakan pengajar di dalam kelas, tetapi pada prinsipnya meliputi segala sesuatu yang ada di lingkungan peserta didik dimana mereka berinteraksi dan membantu proses belajar mengajar.

Secara umum media pembelajaran dapat dikelompokan menjadi tiga, yaitu; pertama, media visual, yaitu suatu jenis media yang semata-mata hanya memanfaatkan indera penglihatan peserta didik untuk menyampaikan pesan pembelajaran. Kedua, media audio, yaitu jenis media pembelajaran dengan hanya melibatkan indera pendengaran peserta didik. Ketiga, media audio-visual, adalah jenis media yang digunakan dalam kegiatan pembelajaran dengan melibatkan indera penglihatan dan indera pendengaran dalam suatu proses atau kegiatan.

Sedangkan Barbabara (Miarso, 1994: 41) mengemukakan bahwa media audio visual adalah cara memproduksi dan menyampaikan bahan dengan menggunakan peralatan mekanis dan elektronis untuk menyajikan pesan-pesan audio visual. Sesuai dengan namanya, media audio visual merupakan kombinasi atau perpaduan audio dan visual. Sudah barang tentu apabila menggunakan media ini akan semakin lengkap dan optimal untuk menunjang kegiatan pembelajaran dan penyajian bahan ajar kepada peserta didik, 
selain itu dengan media ini dalam batasan tertentu dapat menggantikan peran dan tugas guru. Dalam hal ini, guru tidak selalu berperan sebagai penyaji materi tetapi karena penyajian materi bisa digantikan oleh media, maka peran guru bisa beralih menjadi fasilitator belajar, yaitu memberikan kemudahan bagi peserta didik untuk belajar. Oleh karena itu, dengan adanya media pembelajaran berbasis audio visual ini para santri atau siswa mendapatkan sebuah variasi baru dalam hal belajar, adanya variasi baru dalam belajar tersebut diharapkan dapat menumbuhkan semangat dan minat belajar siwa yang berada dalam pesantren.

Media pembelajaran audio visioal pada era globalisasi yang kita rasakan sekarang sangat cocok untuk menerapkan media yang kami kaji ini,dikarenakan untuk menambahkan variasi pembelajaran dan mampu menciptakan pemelajaran yang efektif terhadap guru dan murid salah satunya ialah mencegah rasa bosan yang sering kali timbul didalam diri murid dan seorang guru.

\section{Metode Penelitian}

Penelitian ini dilakukan pada awal pembukaan ajaran baru. Adapun pelaksanaan penelitian ini dilakukan berdasarkan jadwal yang sudah di tetapkan oleh pihak sekolah yang berada di dalam kawasan pesantren tersebut. Tempat penelitian dilakukan di kawasan pesantren Ainul Hasan yang terletak di jalan KH. Moh Hasan, desa Wonorejo, kecamatan Maron, kabupaten Probolinggo. Populasi dan sampel penelitian ini diambil dari dalam kawasan pesantren Ainul Hasan. Instrument yang digunakan dalam penelitian ini adalah: Lembar wawancara, Lembar observasi, dan Lembar catatan lapangan.

Penelitian ini dilakukan dengan cara mengumpulkan data berdasarkan hasil tugas siswa berupa tulisan, wawancara dengan pengajar dan peserta didik, serta proses pembelajaran berlangsung. Peneliti membandingkan hasil catatan yang dilakukan peneliti sendiri dengan catatan guru. Hasil penelitian ini dilakukan secara deskriftif kuantitatif dengan memperoleh data kuantitatif. Penelitian deskriftif kuantitatif merupakan suatu penelitian yang mempunyai tujuan untuk mendeskripsikan suatu fenomena, peristiwa, gejala, dan kejadian secara faktual, sistematis, serta akurat.

\section{Hasil dan Pembahasan}

\section{Penggunaan Media Pembelajaran Audio Visual dalam Pembelajaran}

Belajar merupakan suatu proses yang kompleks yang terjadi pada diri setiap orang sepanjang hidup. Proses belajar itu terjadi karena adanya interaksi antara seseorang dengan lingkungannya yang saat ini kita rasakan pada era globalisasi. Kita dapat mengetahui orang itu telah belajar tatkala mereka telah menjalani hidup, mengambil difenisi belajar cangkupannya sangat luas bukan hanya dikelas saja, akan tetapi diluar forum sekolah kita dapat mempelajari sesuatu hal ini yang biasanya disebut dengan pengalaman.dan sisusul bahwa seseorang itu dapat dikatakan telah belajar adalah adanya perubahan tingkah laku 
Hasan Mubarok, Moh. Umar Aliansyah, Sofiyatun Maimunah, dan Magfirotul Hamdiah

pada diri orang itu yang mungkin disebabkan oleh terjadinya perubahan tingkat pengetahuan, ketrampilan, atau sikapnya (Arsyad, 2011: 1).

Hakikatnya proses belajar mengajar adalah proses komunikasi. Kegiatan belajar mengajar di kelas merupakan suatu dunia komunikasi tersendiri dimana guru atau dosen dan siswa bertukar pikiran untuk mengembangkan ide dan pengertian. Dalam komunikasi sering timbul dan terjadi penyimpangan-penyimpangan sehingga komunikasi tersebut tidak efektif dan efisien, antara lain disebabkan oleh adanya kecenderungan verbalisme, ke tidak pastian siswa, kurangnya minat dan bergairahan.

Kami telah meneliti beberapa pemecahan masalah untuk mengatasi kesulitan belajar ialah dengan memanfaatkan perkembangan zaman, dengan menggunakan penggunaan media secara terintegrasi dalam proses belajar mengajar, karena fungsi media dalam kegiatan tersebut disamping sebagai penyaji informasi, sikap, juga untuk meningkatkan keserasian dalam penerimaan. Media juga berfungsi untuk mengatur langkah - langkah kemajuan serta untuk memberikan umpan balik. Tentunya hal ini didukung oleh salah satu media yang dapat mengefesienkan serta mengkondusifkan suatu pembelajaran yang terdapat dalam lingkungan pesantren yang berbasis modern bahkan salaf.

Penerapan media audio visual ini telah diterapkan disebagian pondok-pondok yang berbasis salaf yang kami teliti ialah pondok Ainul hasan, disana telah menggunakan berbagai teknologi diantanya projector, hp, leptop dan lain-lain untuk membantu dalam pembelajaran yang terdiri dari seorang guru serta peserta didik,bukan hanya itu teknologi yang digunakan dalam pondok Ainul Hasan untuk menciptakan suatu hal yang baru yang dapat menciptakan keharmonisan, mencegah kebosanan, kenapa hal tersebut bisa berdampak kebosanan dan menciptakan ke kondusifan? Dikarenakan santri zaman old telah mengenal serta menggunakan teknologi-teknologi yang berbasis audio visual. Seperti, hp, leptop, projector, dan lain-lain.

Media audio visual semisal projector ini digunakan tatkala santri mengkaji kitab kuning, dan kitab-kitab lainnya, dan hal yang ditekankan dalam sutu pengkajian dipondok itu melatih pendengaran, penglihatan, ketangkapan, pemahaman, dan lain-lain.

\section{Pengertian Media Pembelajaran Audio Visual}

a. Media

Media berasal dari bahasa latin dan merupakan bentuk jamak dari medium yang secara harfiah berarti perantara atau pengantar. Media adalah perantara atau pengantar pesan pengertian ke penerima pesan (Sadiman, 1993: 13). Tentunya hal yang bersifat perantara ialah untuk memudahkan suatu penyampaian segala aspek apapu terlebih dalam proses pembelajaran.

Menurut Hamzah (2011: 113) media merupakan alat komunikasi yang digunakan untuk membawa suatu informasi dari suatu sumber kepada penerimanya. Maksudnya ialah, media segala sesuatu yang dapat digunakan oleh seorang guru sebagai perantara untuk menyalurkan pesan kepada siswa sehingga dapat merangsang pikiran, perasaan, perhatian 
dan minat siswa sedemikian rupa sehingga terjadi proses belajar (membuat pengaruh yang lebih besar kepada penerimanya), dan membuat pengaruh juga terhadap komunikator, yang berupa untuk memudahkan penerasferan suatu materi dalam pembelajaran.

b. Pembelajaran

Pembelajaran adalah proses yang mana suatu kegiatan berasal atau berubah lewat reaksi dari suatu kejadian, dan perubahan yang terjadi bukan perubahan secara alamiah tetapi reaksi dari situasi yang dihadapi (Yogiyanto, 2007: 12). Pembelajaran merupakan proses interaksi antara individu dan lingkungan sekitarnya yang berpengaruh terhadap perilaku dan berhubungan erat dengan pengajaran, dimana seseorang akan belajar dari apa yang diajarkan kepadanya (Huda, 2014: 2).

\section{c. Audio Visual}

Audio visual adalah produksi dan penggunaan materi yang penyerapanya melalui pandangan dan pendengaran serta tidak seluruhnya tergantung kepada pemahaman kata atau simbol - simbol yang serupa agar para siswa mampu termotivasi dalam mengikuti pelajaran (Darwanto, 2007:101). Menurut Sukiman (2012: 184) audio visual adalah media penyalur pesan dengan memanfaatkan indera pendengaran dan penglihatan. Jadi bisa disimpulkan bahwa media pembelajaran audio visual adalah perantara atau alat peraga yang digunakan oleh guru dalam kegiatan beajar mengajar yang produksi dan penggunaan materi yang penyerapannya melalui pandangan (gambar) dan pendengaran (suara).

\section{Kesimpulan}

Penelitian ini mengungkapkan pembelajaran menggunakan audio visual di pesantren Ainul Hasan yang masih belum terjamah atau menerapkan media audio visual, yang membantu untuk lebih mengefesienkan pembelajarn yang ada di dalam pondok pesantren Ainul Hasan.

Pembelajaran di dalam pondok pesantren Ainul Hasan sebelumnya tidak menggunakan media audio visual, hal ini berdampak menubuhkan rasa bosan yang disebabkan media yang monoton dan sistematis pembelajaran yang monoton, sehingga banyak terjadi ketidak kondusifan serta ketidak efektifan dalam pembelajarannya. Namun sekarang pondok pesantren telah berbaur dengan era globalisasi dan menyertakan dalam pembelajarannya menggunakan media yang berbasis audio visul, dan terbukti dengan masuknya media ini dan sistem pembelajaran yang tidak monoton, kini dapat menimbulkan suatu hal yang jauh lebih baik. 


\section{Bibliografi}

Arikunto, Suharsini. 2010. Prosedur Penelitian Suatu Pendekatan Praktik. Jakarta: PT Rineka Cipta.

Darmayanti, Pertiwi. 2009. "Keefektifan Penggunaan Media VCD dalam Pembelajaran Menyimak Berita Pada Siswa Kelas X SMAN Godean,” Skripsi. Yogyakarta: Universitas Negeri Yogyakarta..

Hamzah, Suleman Amir. 1985. Media Audiovisual untuk Pengajaran, Penerangan, dan Penyuluhan. Jakarta: Gramedia Pustaka Utama.

Susanti, Neng Dwi. 2012. "Keefektifan Media Audio Visual Dalam Pembelajaran Apresiasi Puisi Pada Siswa Kelas X SMA Negeri 3 Sukoharjo” Skripsi. Yogyakarta. Universitas Negeri Yogyakarta.

Arikunto, Suharsimi dan Cepi Safiruddin Abdul Jabbar. Evaluasi Program Pendidikan. Jakarta: Bumi Aksara, 2007.

Arsyad, Azhar. Media Pembelajaran. Jakarta: PT Raja Grafindo Persada, 2011.

Dimyati dan Mudjiono. Belajar dan Pembelajaran. Jakarta: Rineka Cipta, 1999.

Fujiyanto, Ahmad, dkk. "Penggunaan Media Audio Visual untuk Meningkatkan Hasil Belajar Peserta didik pada Materi Hubungan antar Makhluk Hidup”. Jurnal Pena Ilmiah 1, no.1 (2016).

Sugiyono. Metode Penelitian Kuantitatif Kualitatif dan R\&D. Bandung: Alfabeta, 2011. 